\title{
Landasan Ontologis Pengembangan Antropologi Pancasila
}

\author{
Surono ${ }^{1}$, Rr. Siti Murtiningsih ${ }^{2}$, Heri Santoso ${ }^{3}$ \\ 'Sekolah Pascasarjana UGM, UGM Yogyakarta, Indonesia \\ ${ }^{2,3}$ Fakultas Filsafat, UGM Yogyakarta, Indonesia \\ E-mail: suronokarti@ugm.ac.id ${ }^{1}$, stmurti@ugm.ac.id², herisantoso@ugm.ac.id ${ }^{3}$
}

\begin{abstract}
Abstrak
Hegemoni Barat terhadap keilmuan sosial humaniora di Indonesia sudah sangat berpengaruh, termasuk dalam Antropologi. Kondisi tersebut mengakibatkan munculnya rasa rendah diri terhadap teori-teori asing dan ketidakpercayaan terhadap teori-teori yang lahir dari pemikiran imuwan-ilmuwan Indonesia. Para ilmuwan Indonesia terjebak dalam penjara ideologi Barat. Penelitian ini bertujuan untuk melakukan pengembangan pemikiran dan produksi pengetahuan terhadap Antropologi (Pancasila khususnya). Sehingga, akan tersusun bangunan ilmiah bidang Antropologi yang berlandaskan nilai-nilai keindonesiaan (Pancasila). Pada tulisan ini akan difokuskan pada bagaimana landasan pengembangan Antropologi Pancasila pada dimensi ontologis. Pendekatan penelitian kualitatif digunakan dengan kajian yang berhubungan dengan Antropologi dan Pancasila. Hasil penelitian menunjukkan bahwa Antropologi Pancasila memiliki ciri pembeda dengan Antropologi yang berkembang saat ini dalam hal dasar nilai yang dijadikan dasar untuk menilai kebenaran-kesalahan, kebaikan-keburukan, dan lain-lain. Dasar ontologis Antropologi Pancasila adalah keyakinan prinsipial yang diturunkan dari nilai-nilai Pancasila.
\end{abstract}

Kata kunci: antropologi pancasila; kepancasilaan; keindonesiaan; ontologis

\begin{abstract}
The Western hegemony in the social sciences and humanities has influenced Indonesian scientists, including the Anthropologists. This condition caused Indonesian scientists had an inferiority towards the foreign theories and distrust of the thoughts of Indonesian scientists. Indonesian scientists are trapped in the confines of Western ideology. This study aims to develop the Pancasila Anthropology, i.e the scientific buildings of Anthropology based on the Indonesian values (especially Pancasila). This paper will be focus on how to developing the ontological dimension of Pancasila Anthropology. Qualitative research methods and materials obtained from literature related to the Anthroology and Pancasila were used in this work. The results of this study show that Pancasila Anthropology has a different character from current Anthropology in terms of the basic of values that are used as a basis for judging right-wrong, good-bad, and so on. The ontological basis of the Pancasila Anthropology is the principal belief that derived from the values of Pancasila.
\end{abstract}

Keywords: about pancasila, indonesianness; ontology; pancasila anthropology.

\section{Pendahuluan}

Para kritikus menegaskan bahwa Antropologi (lapangan khususnya) memiliki hubungan dengan suatu kekuasaan Barat tertentu. Apakah hubungan tersebut formal atau tidak, umumnya Antropologi melaksanakan kerjanya pada suatu pengaruh kolonial tertentu (Kaplan \& Manners, 1999). Walaupun, ada ahli yang mengatakan bahwa Antropologi telah merevolusi diri dengan pemikiran-pemikiran modern seperti yang dilakukan oleh William Du Bois and Franz Boas (Pels, 2018). Dalam upaya menjawab tantangan tersebut, maka penulis berupaya untuk mendesain ilmu Antropologi yang "terbebas" dari pengaruh Barat. Antropologi yang dimaksud adalah Antropologi yang dibangun berdasarkan nilai-nilai keindonesiaan, yaitu Antropologi Pancasila.

Artikel ini ingin membahas konsep yang paling dasar dari Antropologi Pancasila, yakni landasan ontologis Antropologi Pancasila. Ontologi membahas tentang hakikat yang paling dalam dari sesuatu yang ada, yaitu unsur yang paling umum dan bersifat abstrak. Inti persoalan dari ontologi yaitu menganalisis tentang substansi (Taylor, 2015).

Sebelum membahas Antropologi Pancasila, kiranya perlu dibahas secara singkat tentang apa itu Antropologi. Sebagaimana diketahui bahwa Antropologi merupakan salah satu cabang ilmu humaniora yang berkembang cukup baik di dunia, demikian pula halnya di Indonesia. Antropologi hadir dengan tujuan untuk menjelaskan dan memahami keberagaman manusia di dunia. Khususnya Antropologi Budaya, untuk mendapatkan hasil yang maksimal diperlukan pemahaman yang mendasar terhadap manusia. Seorang ahli Antropologi harus mampu menjawab pertanyaan: Apa hakikat manusia? Apa dan siapa sebenarnya manusia itu? (Bakker, 2000). 
Ditinjau dari aspek historis, awal mula kemunculan Antropologi sangat dipengaruhi oleh kebiasaan ekspedisi/perjalanan bangsa Eropa Barat ke hampir seluruh penjuru dunia. Meski banyak sisi negatif yang dihasilkan dari petualangan orang-orang Eropa Barat tersebut, namun ada sisi positif yang dapat diambil. Salah satu sisi positif dari hasil perjalanan bangsa-bangsa Eropa Barat tersebut adalah terkumpulnya bahan-bahan etnografi dari berbagai suku bangsa di dunia. Bahan-bahan etnografi ini nantinya yang akan menjadi embrio lahirnya Antropologi. Bahan-bahan etnografi dari berbagai suku bangsa di dunia disimpan dan dikelompokkan berdasarkan tata urutan perkembangannya, yang pada kemudian melahirkan teori-teori evolusi kebudayaan, kemudian disusul aliran difusi, fungsionalisme, dan seterusnya.

Sayangnya, perjalanan bangsa-bangsa Eropa Barat ke berbagai belahan dunia ini juga memunculkan semangat menguasai kepada suku bangsa yang dikujungi, sehingga kemudian munculah kolonialisasi terhadap bangsa-bangsa di luar Eropa. Pada era kolonialisasi inilah Antropologi secara langsung maupun tidak langsung menjadi salah satu ilmu yang ikut bertanggung jawab. Salah satu contoh nyatanya adalah penjajahan terhadap Indonesia yang melibatkan antropolog dunia, yakni Snouck Hurgronje. Seperti diketahui bahwa Hurgronje memulai misinya di Aceh pada tanggal 16 Juli 1891 dan tinggal di Aceh sampai tanggal 4 Februari 1892. Petualangan dan penyamarannya mampu memberikan keutungan yang sangat besar bagi Belanda untuk menguasai Aceh setelah puluhan tahun Belanda mencobanya.

Hal ini sesuai dengan apa yang disampaikan Koentjaraningrat yang menyusun fase perkembangan Antropologi menjadi empat fase. Fase pertama (sebelum Tahun 1800), yang ditandai dengan ekspedisi bangsa Eropa Barat ke berbagai benua, seperti Asia, Afrika, dan Amerika. Dari para penjelajah tersebut terkumpul buku-buku kisah perjalanan, yang berisi bahan pengetahuan berupa deskripsi tentang adat istiadat, susunan masyarakat, bahasa, dan ciri-ciri fisik dari bermacam-macam suku bangsa di Asia, Afrika, Oseania, dan Amerika. Fase kedua (tahun 1800-an), munculnya berbagai karangan yang menyusun bahan-bahan etnografi berdasarkan cara berpikir evolusi masyarakat saat itu, yang berevolusi dalam jangka waktu lama dari tingkat sederhana ke tingkat yang kompleks. Fase ketiga (awal tahun 1900an), pada fase ini Antropologi digunakan untuk kepentingan kolonialisme. Antropologi menjadi ilmu praktis yakni dengan mempelajari masyarakat dan kebudayaan modern. Fase keempat (setelah tahun 1900-an), Antropologi lebih memfokuskan diri pada pengembangan keilmuan dan tidak lagi hanya mengkaji masyarakat pedesaan di luar Eropa, tetapi juga kepada seluruh suku bangsa di Eropa (Koentjaraningrat, 1981).

Jika ditinjau secara etimologis, Antropologi berasal dari kata anthropos (manusia) dan logos (ilmu), dalam arti luasnya adalah ilmu tentang manusia. Antropologi adalah disiplin ilmu yang menjadikan manusia sebagai subjek sekaligus objek kajian. Antropologi mengkaji manusia secara menyeluruh manusia baik fisik maupun nonfisiknya. Menurut Koentjaraningrat (1981), Antropologi mengkaji manusia yang berhubungan dengan masalah sejarah terjadinya dan perkembangannya, sejarah terjadinya aneka warna ciri fisik manusia, persebaran dan terjadinya aneka warna bahasa, perkembangan, persebaran, dan terjadinya aneka warna kebudayaan manusia, dasar-dasar dan aneka warna kebudayaan manusia dalam kehidupan masyarakat dan suku-suku bangsa di dunia.

Secara terminologis, Antropologi dimaknai secara berbeda oleh para pakar. Sejumlah pandangan para ahli tentang Antropologi di antara sebagai berikut:

1. William A. Havilland berpendapat bahwa Antropologi adalah studi tentang umat manusia, berusaha menyusun generalisasi yang bermanfaat tentang manusia dan perilaku manusia, serta untuk memperoleh pengertian yang lengkap tentang keanekaragaman manusia.

2. David Hunter berpandangan bahwa Antropologi adalah ilmu yang lahir dari keingintahuan yang tidak terbatas tentang umat manusia.

3. Koentjaraningrat berpendapat bahwa Antropologi adalah ilmu yang mempelajari umat manusia pada umumnya dengan mempelajari aneka warna-warna, bentuk fisik suatu masyarakat serta kebudayaankebudayaan yang dihasilkan.

Jika ditinjau dari bidang kajiannya, Antropolgi dapat dibedakan menjadi dua, yaitu Antropologi fisik dan budaya. Antropologi fisik mempelajari manusia sebagai organisme, dalam konteks ini Antropologi mengkaji perkembangan manusia berdasarkan evolusi dan variasi biologis dalam berbagai jenis (spesies). Antropologi budaya memfokuskan kajian pada kebudayaan manusia termasuk cara hidupnya dalam masyarakat. Cabang Antropologi budaya ini dibagi-bagi lagi menjadi tiga bagian, yakni arkeologi, antroplogi linguistic, dan etnologi (Haviland, 1999). Artikel ini akan fokus pada Antropologi ranah budaya.

Selain ditinjau secara historis, etimologis, dan terminologis di atas, maka untuk menggali landasan ontologis Antropologi Pancasila, kiranya perlu dibahas terlebih dahulu aliran-aliran pemikiran yang berkembang dan turut mewarnai Antropologi hingga dewasa ini. Sehingga, akan tampak jelas corak pemikiran Antropologi Pancasila yang ingin ditawarkan. Perkembangan aliran-aliran pemikiran dalam Antropologi Ini tidak dapat dilepaskan dari perkembangan aliran-aliran pemikiran kefilsafatan dan paradigmatik metodologik Barat dalam ilmu sosial budaya lainnya. Ada banyak aliran pemikiran yang 
berkembang dalam Antropologi, namun dalam tulisan ini dibatasi pada empat aliran utama yang cukup mendominasi pemikiran Antropologi hingga dewasa ini, yakni positivisme, kritisisme, fenomenologi, dan postmodernisme. Pemilihan ini tidak bermaksud untuk mengabaikan aliran-aliran Antropologi lainnya, namun untuk menunjukkan kekhasan pemikiran Antropologi Pancasila.

Positivisme, aliran pemikiran ini tidak dapat dilepaskan dari nama tokohnya, yaitu August Comte. Comte dan kawan-kawannya berpandangan bahwa kebenaran yang bersifat alamiah atau empiris dan dapat diterangkan secara ilmiah. Positivisme sangat mengandalkan logika dan pengalaman untuk menjelaskan suatu fenomena yang akan menuju pada kesimpulan logis. Aliran ini memiliki corak pemikiran antara lain: menolak aktivitas yang berkenaan dengan metafisik, tidak spekulatif, dan semua harus didasarkan pada data empiris. Tokoh-tokoh Antropologi yang termasuk dalam aliran positivisme beberapa di antaranya adalah Emile Durkheim dan Talcott Person.

Kritisisme, merupakan kritikan keras terhadap aliran yang mendewa-dewakan logika. Walaupun logika memiliki kemampuan yang sangat luar biasa, namun memiliki keterbatasan. Aliran yang dipelopori oleh Immanuel Kant ini berusaha melakukan penyadaran atas kemampuan akal secara objektif dan menentukan batas-batas kemampuannya. Keterbatasan logika manusia dilengkapi dengan iman kepercayaan yang berfungsi sebagai penyempurna atas keterbatasan pengetahuan manusia tersebut. Kritisisme merupakan sintesis dari rasionalisme dan empirisme yang berkembang sebelumnya.

Fenomenologi, sering diartikan sebagai suatu upaya untuk menjelaskan dan memahami fenomena sosial budaya berdasarkan kesadaran pengalaman manusia sebagai pengalaman subjektif atau sudut pandang orang pertama. Fenomenologi memungkinkan terjadinya pengkajian fenomena dengan cara memahami keunikan orang yang diteliti. Aliran Fenomenologi inilah yang sering dikaitkan ontologi, epistemologi, logika, dan etika. Fenomenologi tidak hanya berhenti pada deskripsi tetang pengalaman-pengalaman pribadi, namun sampai pada pemaknaan individu terhadap fenomena. Edmund Husserl menyebutkan Fenomenologi merupakan transcendental science yang tidak sama dengan naturalistic science. Fenomenologi kurang berfokus pada generalisasi (seperti di dalam ilmu alam) akan tetapi pada makna yang ada di dalam pengalaman manusia.

Postmodernisme, atau kadang disebut pascamodernisme, adalah kritik terhadap aliran Modernisme yang mengagung-agungkan konsep-konsep berkaitan dengan rasionalisasi, teknologisasi, kebenaran tunggal, dan antroposentrisme. Aliran ini banyak membahas fenomena globalisasi, konsumerisme, fragmentasi gaya hidup, konsumerisme yang berlebihan, sampai dengan menggali inspirasi-inspirasi yang berhubungan dengan tradisi. Semangat utama yang diusung adalah semangat dekonstruksi, relativisme, dan menolak kebenaran tunggal. Tokoh-tokohnya yang banyak dikenal antara lain: J.Baudrillard, J.F. Lyotard, dan Richard Rorty. Sebagian ahli mengatakan jika postmodernisme tidak bisa dimasukkan dalam ilmu pengetahuan, tetapi hanya semangat, karena postmodernisme bukanlah paham tunggal/teori. Akan tetapi, hanya sebuah wadah teori-teori yang ada dan sulit ditemukan asas tunggalnya.

Selain empat aliran pemikiran kefilsafatan atau paradigm metodologis di atas, Ahimsa-Putra secara berbeda mengidentifikasi ada 15 (lima belas) paradigma di dalam Antropologi budaya, yang berkembang sampai saat ini. Kelimabelas paradigma tersebut antara lain: evolusionisme (evolusi kebudayaan), diffusionisme (difusi kebudayaan), partikularisme historis, fungsionalisme, cross-cultural comparison, analisis variabel, kepribadian kebudayaan, tafsir kebudayaan, strukturalisme (Levi-Stauss), etnosains, materialisme budaya, materialisme historis, konstruksionalisme (fenomenologi sosial), actor oriented, dan postmodernism (Ahimsa-Putra, 2008).

\section{Metode Penelitian}

Metode yang digunakan dalam penelitian ini adalah penelitian pustaka. Bahan utama yang digunakan meliputi data kepustakaan berupa berbagai konsep dan pemikiran tentang Antropologi serta Pancasila. Bahan ini diperoleh dari berbagai pustaka, baik daring maupun luring. Untuk mendapatkan pemahaman yang komprehensif, maka akan dicari juga data sejarah serta karya-karya yang berkaitan dengan Antropologi dan Pancasila.

Model yang digunakan dalam penelitian ini adalah sistematis reflektif (Bakker \& Zubair, 1990). Penelitian ini mencari data utama berupa kepustakaan. Objek material dari penelitian ini adalah pemikiran-pemikiran tentang Antropologi Pancasila dan relevansinya dalam pengembangan Antropologi di Indonesia. Objek formal penelitian ini adalah dengan sudut pandang kefilsafatan, secara khusus adalah filsafat ilmu.

\section{Hasil dan Pembahasan}

\section{a. Aliran Pemikiran Pancasila dalam Keilmuan}

Setelah memahami apa itu Antropologi secara etimologis, terminologis, historis, dan paradigmatis maka untuk memahami landasan ontologis Antropologi Pancasila perlu dibahas terlebih dahulu tentang 
aliran pemikiran Pancasila dalam keilmuan.

Pancasila, secara etimologis berasal dari bahasa Sansekerta yang tersusun dari kata panca dan syila. Panca memiliki arti lima dan syila adalah alas atau dasar. Pancasila data diartikan lima dasar (aturan) yang harus ditaati dan dilaksanakan. Secara terminologis, istilah Pancasila pertama kali diperkenalkan oleh Soekarno pada pidatonya di hadapan peserta sidang BPUPK (Dokuritsu Ziumbi Tyoosakai) pada tanggal 1 Juni 1945.

Dalam hal fungsi dan kedudukan, Pancasila bagi bangsa Indonesia memiliki berbagai fungsi dan kedudukan, misalnya sebagai: dasar negara bangsa Indonesia, pandangan hidup, ideologi bangsa Indonesia, jiwa bangsa Indonesia, sumber dari segala sumber tertib hukum, kepribadian bangsa Indonesia, cita-cita dan tujuan yang akan dicapai bangsa Indonesia, perjanjian luhur, falsafah hidup, dan lain sebagainya.

Pembahasan tentang Pancasila pada diskusi ini akan memfokuskan diri pada pertanyaan mungkinkan Pancasila yang berkedudukan sebagai ideologi bangsa yang bercirikan doktrin-ideologis menjadi ilmiah akademis. Karena ideologi memiliki sifat cenderung terselubung, sementara akademis bersifat terbuka. Pengajaran Pendidikan Pancasila selama ini sering kali dianggap sebagai doktrin ideologis yang bersifat tertutup. Padahal, dunia akademis merupakan wilayah yang sangat cair dan fleksibel sehingga pembelajaran Pancasila yang kaku (rigorous) menjadikan suasana kelas yang membosankan bahkan kejengkelan yang bisa memunculkan sikap tidak produktif terhadap nilai-nilai Pancasila (Mustansyir, dkk., 2018).

Dalam perkembangan selanjutnya, diskusi tentang Pancasila menghasilkan berbagai pemikiran yang semakin komplek dan bervariasi. Berbagai pemikiran tentang Pancasila tersebut dijelaskan oleh Pranarka sebagai berikut, bahwa Pancasila heterogenitas pada (1) cara merumuskan unsur-unsurnya; (2) cara menguraikan argumentasinya; (3) statusnya; (4) apresiasi terhadap Pancasila; (5) sumber Pancasila; (6) tafsirnya; (7) pendekatan intelektualnya (Pranaka, 1985). Kompleksitas pemikiran terhadap Pancasila tersebut membawa implikasi pada sulitnya merumuskan pandangan filosofisnya. Kesulitan tersebut terasa bertambah karena Pancasila bukanlah filsafat sebagai karya pribadi melainkan karya komunal dan hasil intersubyektif dan idealisme bangsa Indonesia (Santoso, 1999).

Perlu diketahui bahwa sistem filsafat itu merupakan satu bagan konsepsional yang bersifat rasional yang mempunyai ciri bersifat menyeluruh, koheren, mendasar, dan spekulatif (Bakry, 1994). Sistem kefilsafatan merupakan kumpulan dari ajaran-ajaran tentang kenyataan, yang saling berhubungan sehingga merupakan kesatuan, komprehensif, dan dimaksudkan untuk tujuan tertentu. Dalam hal ini, subjektif dibentuknya sistem filsafat adalah kesadaran dari pelaku atau pembentuk sistem tersebut untuk menerapkan sistem itu dalam rangka tujuan tertentu atau ideal (Mudhofir, 1996). Pertanyaan berikutnya adalah, apakah Pancasila bisa dikategorikan sebagai sistem filsafat?

Untuk menguji apakah Pancasila merupakan sistem filsafat maka akan diuraikan beberapa pandangan berikut ini. Notonagoro (1975) menyatakan bahwa Pancasila merupakan kesatuan yang bersifat organis, terdiri dari beberapa bagian yang tidak terpisahkan satu dengan lainnya,

"Sedangkan sebenarnya sila-sila itu bersama-sama merupakan bagian-bagian dari suatu keutuhan, merupakan bagian-bagian dalam hubungan kesatuan".

Pancasila merupakan hasil perenungan yang mendalam dari tokoh kenegaraan Indonesia. Hasil perenungan terhadap Pancasila tersebut pada awalnya bertujuan untuk merumuskan dasar negara yang akan merdeka dan bisa dikategorikan sebagai sistem filsafat karena telah memenuhi beberapa ciri berpikir kefilsafatan. Ciri-ciri tersebut adalah (1) sistem filsafat harus koheren yakni berhubungan satu dengan lainnya secara runtut dan tidak mengandung pernyataan yang saling bertentangan (Pancasila tidak saling bertentangan bahkan saling melengkapi); (2) harus bersifat menyeluruh, mencakup segala hal dan gejala yang terdapat dalam kehidupan manusia (Pancasila sebagai filsafat hidup bangsa Indonesia memenuhi syarat ini); (3) sistem filsafat harus bersifat mendasar, yakni sebagai bentuk perenungan mendalam yang sampai pada inti mutlak permasalahan sehingga menemukan aspek fundamental (Pancasila dirumuskan berdasarkan inti mutlak tata kehidupan manusia dalam menghadapi pribadinya, antar sesama, dan Allah; (4) bersifat spekulatif, buah pikir hasil dari suatu perenungan mendalam sebagai praanggapan yang menjadi awal mula yang kemudian menjadi pola dasar melalui penalaran logis dan menjadi titik pangkal pemikiran tentang sesuatu (Pancasila pada awalnya adalah buah pemikiran tokoh-tokoh kenegaraan sebagai pola dasar yang kemudian dibuktikan kebenarannya melalui diskusi pada sidang BPUPK sampai dengan PPKI) (Bakry, 1994). Pemikiran terhadap Pancasila merupakan suatu proses yang berlangsung secara kontinu sehingga perenungan awal yang dicetuskan para pendiri negara merupakan bahan baku yang dapat dan akan terus merangsang pemikiran para pemikir berikutnya (Santoso, dkk. 2016). Berdasarkan penjelasan di atas maka Pancasila bisa dimasukkan ke dalam sistem filsafat.

Pancasila sebagai sistem filsafat merupakan dasar yang sangat penting dalam upaya 
pengembangan ke ranah ilmiah. Pancasila merupakan bahan renungan para pendiri bangsa, salah satunya adalah Soekarno pada saat menggagas ide tentang philosofische grondslag. Perenungan Soekarno ini menuju upaya untuk menemukan nilai-nilai filosofis yang menjadi identitas bangsa Indonesia. Perenungan tersebut kemudian berlanjut pada sidang Badan Penyelidik Usaha-usaha Persiapan Kemerdekaan (BPUPK) tanggal 29 mei - 1 Juni 1945 sampai pada pengesahan Pancasila menjadi dasar negara pada tanggal 18 Agustus 1945 pada siding Panitia Persiapan Kemerdekaan Indonesia (PPKI).

Pendekatan filosofis Pancasila tersebut sarat dengan perenungan filosofis sebagaimana terlihat dalam pemikiran Soekarno tentang philosofische grondslag. Peletakan dasar filosofis tersebut bertumpu pada tiga landasan, yakni ontologis, epistemologis, dan aksiologis. Landasan ontologis dimaksudkan untuk memberikan kerangka pikir tentang kedudukan Pancasila sebagai way of life (weltan scahuung). Hal ini diperlukan karena ranah ontologis merupakan mode of being sila-sila Pancasila dalam kehidupan bangsa Indonesia. Epistemologis menempatkan Pancasila sebagai way of thinking yang meliputi dari mana sumber pengetahuan tentang sila-sila Pancasila, bagaimana validitas pengetahuan tentang silasila tersebut, dan bagaimana koherensi logis hubungan antar sila. Landasan aksiologis, bahwa prinsip utama pada sila-sila Pancasila merupakan prinsip moral (source of values) yang menuntut bangsa Indonesia untuk hidup berdasarkaan spiritualitas, humanitas, unitas, musyawarah, dan keadilan (Mustansyir, dkk., 2018:6).

Pancasila dalam kajian keilmuan dapat dikategorikan menjadi dua, yaitu Pancasila sebagai genetivus objectivus dan genetivus subjectivus. Pancasila sebagai Genetivus objectivus diartikan nilainilai Pancasila dijadikan sebagai obyek kajian yang dicari landasan filosofisnya berdasarkan sistemsistem dan cabang-cabang filsafat yang berkembang di Barat. Misalnya Pancasila dikaji menggunakan pendekatan eksistensialisme religius seperti yang dilakukan oleh Drijarkara. Pancasila sebagai genetivus subjectivus, bahwa nilai-nilai Pancasila digunakan untuk mengkritisi berbagai aliran filsafat untuk menemukan hal-hal yang sesuai dan juga yang tidak sesuai dengan nilai-nilai Pancasila.

\section{b. Antropologi Pancasila}

Setelah mengenal Antropologi dan Pancasila dalam keilmuan, maka uraian berikut difokuskan untuk mengkaji dasar eksistensi dan justifikasi adanya Antropologi Pancasila. Gagasan tentang Antropologi Pancasila merupakan upaya pengembangan pemikiran dan produksi pegetahuan terhadap Antropologi dan Pancasila khususnya. Salah satu alasan dilakukannya upaya ini adalah mengingat kajian pengembangan keilmuan ranah filosofis, khususnya ilmu sosial humaniora, dewasa ini cenderung stagnan. Hasil akhir dari kajian ini adalah sebuah konsep keilmuan yang mengkaji manusia dari sudut pandang Indonesia. Hal ini juga dimaksudkan sebagai upaya mengimbangi Antropologi yang dikembangkan di Indonesia dengan menggunakan sudut pandang pendekatan yang belum berkarakter Indonesia. Secara singkat dapat dikatakan bahwa Antropologi Pancasila adalah Antropologi tentang Pancasila dan Antropologi yang dikembangkan berdasarkan filosofi Pancasila. Tulisan ini lebih difokuskan pada makna kedua.

Antropologi Pancasila dalam kajian filsafat khususnya filsafat ilmu berusaha mengkaji konsep ilmu Antropologi yang bercirikan Indonesia. Antropologi adalah ilmu yang mengkaji manusia baik dari aspek fisik maupun budaya. Antropologi lahir dan besar berkat jasa para pemikir dari Eropa Barat. Sedangkan, Pancasila adalah ideologi, way of live, way of thinking, dan filosofi yang lahir, berkembang, dan dijadikan pegangan oleh bangsa Indonesia.

Berdasarkan paparan singkat tersebut terlihat bahwa antara Antropologi dan Pancasila memiliki akar sejarah yang berbeda. Perbedaan tersebut tentunya akan berimplikasi pada adanya perbedaan ruh dan semangat di antara keduanya. Antropologi secara historis, disadari atau tidak telah membawa ruh/semangat/spiritualitas orang Eropa, sementara Pancasila merupakan kristalisasi nilai-nilai keindonesiaan yang tentunya akan memperjuangkan ruh/semangat/ spiritualitas bangsa Indonesia.

Antropologi Pancasila yang sedang digagas ini difokuskan pada Pancasila sebagai genetivus subjektivis, dalam arti aliran pemikiran filsafat Pancasila digunakan untuk mengkaji aliran pemikiran lain terutama aliran pemikiran di dalam Antropologi. Upaya ini sejalan dengan apa yang digagas oleh Notonagoro, yakni Pancasila sebagai pegangan dan pedoman bagi ilmu pengetahuan, Pancasila sebagai pangkal sudut pandang dalam penyelidikan, pertanggungjawaban ilmiah bagi sila Ketuhanan, fundamental dalam ilmu pengetahuan, soal teori kenyataan, soal sebab dan akibat, dan soal keadaban, sebagai obyek ilmu pengetahuan tentang negara dan hukum (Notonagoro, 1951).

Secara kelembagaan, hal tersebut juga sesuai dengan gagasan dalam seminar yang dilakukan oleh universitas Gadjah Mada tahun 1986 dengan tema "Pancasila sebagai Orientasi Pengembangan IImu" yang bertujuan untuk menjajagi kompetensi filsafat Pancasila sebagai orientasi pengembangan ilmu pengetahuan (Prawirohardjo, dkk. (ed), 1986). Langkah ini diikuti oleh Badan Pembinaan Pendidikan Pelaksanaan Pedoman Penghayatan dan Pengamalan Pancasila (BP-7) Pusat pada tanggal 24-26 Oktober 1989 di Jakarta: 
Salah satu gerakan pembudayaan itu, yang juga berarti pengamalannya dalam kehidupan nyata, adalah pengembangan pemikiran tentang nilai-nilai Pancasila dan UUD 1945 yang relevan dengan kebutuhan pengembangan masyarakat dan tuntutan perubahan jaman, tetapi tetap berada dalam kerangka paradigma atas kandungan hakikatnya yang sesungguhnya. Sejalan dengan itu pengembangan pemikiran itu bukanlah dimaksudkan untuk merubah atau merevisi apalagi menggantinya. Justru yang ingin dicapai adalah untuk memperkuat, mempermantap dan mengembangkan penghayatan, pembudayaan, dan pengamalan dalam berbagai bidang kehidupan masyarakat, berbangsa, dan bernegara. Melalui pengembangan pemikiran tentang Pancasila dan UUD 1945 seperti itu diharapkan bangsa kita akan dapat melahirkan dan mengembangkan gagasan, konsep-konsep dan bahkan teori-teori baru dalam berbagai bidang kehidupannya yang bersumber dari ideologi dan kosntitusi bersama kita itu, serta pada waktu yang sama berhasil pulamenguatkan relevansinya dengan realita perkembangan masyarakat dan tuntutan perubahan jaman (Oesman dan Alfian (peny.)), 1991).

Upaya kelembagaan lainnya adalah dalam simposium dan sarasehan yang dilaksanakan oleh Universitas Gadjah Mada, KAGAMA, LIPI, dan LEMHANAS pada tanggal 14-15 Agustus 2006 yang bertemakan "Pancasila sebagai Paradigma IImu Pengetahuan dan Pembangunan Bangsa".

Secara substansial, ilmu dengan metode ilmiahnya bertujuan untuk mencapai kebenaran. Kebenaran tidak hanya murni memenuhi kriteria koherensi-korespondensi, deduksi-induksi, dan pemikiran rasional-empiris saja. Tetapi, kebenaran juga harus dikembalikan pada manusianya, dalam kasus ini manusia Indonesia, jati diri bangsa Indonesia. Pancasila sebagai jati diri bangsa Indonesia harus dijadikan dasar pengembangan ilmu. Teori kebenaran Pancasila harus: (1) koherensi antara kebenaran ilmiah dengan nilai-nilai ketuhanan, kemanusiaan, persatuan, kerakyatan, dan keadilan; (2) berkesesuaian dengan kenyataan adanya Tuhan, manusia, satu, rakyat, dan adil; (3) secara pragmatik ukuran kemanfaatannya harus dikembalikan pada kamanusiaan yang berketuhanan, berpersatuan, berkerakyatan, dan berkeadilan (Budisutrisno, 2006).

Akhirnya, Antropologi Pancasila yang akan dikembangkan di sini bukan Antropologi tentang Pancasila, melainkan Antropologi yang menggunakan nilai-nilai Pancasila sebagai landasan filosofis pengembangan Antropologi. Landasan filosofis yang dimaksud adalah landasan ontologis, epistemologis-metodologis, dan aksiologis Antropologi. Antropologi Pancasila dikembangkan berdasarkan nilai-nilai kebenaran, kebaikan, keindahan, kekhudusan dan nilai-nilai dasar lain yang dimiliki bangsa Indonesia. Eksistensi ilmu ini dirasakan urgent didasarkan atas beberapa pertimbangan. Pertama, Antropologi yang dikembangkan di Indonesia, terutama dalam ranah akademik, cenderung menjadikan nilai-nilai budaya Indonesia sebagai objek kajian dengan kaca mata non-Indonesia. Kiranya dibutuhan kehadiran Antropologi yang menjadikan nilai-nilai budaya Indonesia sebagai subyek kajian atau sudut pandang pendekatan. Antropologi Pancasila dirasakan urgent kehadirannya dalam konteks ini. Kedua, Pendekatan-pendekatan Antropologi yang dikembangkan di Indonesia saat ini tidak dapat dipungkiri didominasi oleh teori-teori asing yang secara teoritik maupun aplikatif tidak selalu relevan untuk menjelaskan dan memahami kasus/fenomena sosial budaya Indonesia, bahkan tidak jarang teori-teori asing itu terlalu dipaksakan. Kondisi tersebut disadari atau tidak, Antropologi membawa isme-isme asing yang tidak selalu sesuai bahkan bertentangan dengan karakteristik bangsa Indonesia. Kedua argumen di atas kiranya sudah memadai untuk menunjukkan keabsahan atas eksistensi Antropologi Pancasila untuk dikembangkan di Indonesia.

\section{c. Landasan Ontologis Antropologi Pancasila}

Secara filosofis, khususnya filosofi ilmu, eksistensi ilmu itu kokoh atau rapuh, sama atau berbeda dengan ilmu lain dapat digali dari asumsi-asumsi yang menjadi landasan filosofis pengembangannya. Asumsi-asumsi itu dalam filsafat ilmu dikenal dengan landasan ontologis, epistemologis, dan aksiologis. Kajian landasan ontologis ilmu, membahas seputar persoalan, jawaban, sikap dan keyakinan ilmuwan tentang eksistensi ilmu, objek ilmu, dan asumsi tentang objek ilmu tersebut. Kajian landasan epistemologis ilmu membahas tentang asumsi dan jawaban ilmuan tentang sumber pengetahuan, jenis pengetahuan, metode, dan validitas kebenaran ilmu. Sementara, kajian landasan aksiologis ilmu membahas tentang hubungan ilmu dengan nilai, tujuan pengembangan ilmu dan sikap ilmiah yang harus dijunjung tinggi oleh para ilmuwan.

Mengingat tulisan ini dimaksudkan untuk menggali landasan filosofis ilmu terutama dari landasan ontologis ilmu, maka akan dibahas tiga hal penting, yaitu, pertama, apa argumentasi yang dapat dijadikan dasar justifikasi eksistensi Antropologi Pancasila. Kedua, apa objek kajian Antropologi Pancasila, yang menunjukkan persamaan dan perbedaan dengan objek kajian Antropologi aliran pemikiran yang lain. Ketiga, apa asumsi ilmuwan tentang objek kajian tersebut, sekaligus persamaan dan perbedaan dengan 
asumsi ilmuwan lainnya.

Berdasarkan ketiga persoalan fundamental landasan ontologis ilmu Antropologi Pancasila tersebut, maka Antropologi Pancasila memiliki karakteristik pemikiran sebagai berikut. Pertama, dasar justifikasi urgensi eksistensi Antropologi Pancasila adalah argumentasi berdasarkan objek kajian dan subjek kajian. Berdasarkan objek kajian Antropologi secara kodrati membahas tentang eksistensi dan hakikat manusia, padahal manusia itu memiliki unsur yang bersifat universal, kolektif, dan personal. Pertanyaan mendasarnya adalah apakah Antropologi mainstream selama ini mampu menjelaskan eksistensi dan hakikat manusia secara universal, kolektif, dan personal tersebut secara memuaskan. Asumsi kaum positivistik yang berkeyakinan bahwa ilmu itu bersifat universal kiranya sudah banyak dibantah oleh aliran kritis dan postmodernisme. Artinya, ada ruang-ruang kolektif dan personal yang tidak mampu dibahas secara memuaskan dengan menggunakan pendekatan Antropolologi mainstream. Argumentasi ini dapat dijadikan salah satu dasar justifikasi eksistensi Antropologi Pancasila.

Argumentasi kedua adalah justifikasi berdasarkan subjek kajian. Berdasarkan penelusuran historis perkembangan Antropologi di dunia hingga dewasa ini menunjukkan bahwa Antropologi lahir, tumbuh dan berkembang dalam konteks sosio-historis-kultural. Artinya kontesk sosio-historis-kultural lahirnya Antropologi tidak dapat dilepaskan dari budaya Barat. Pertanyaan yang muncul, apakah Antropologi demikian steril dari -isme, paham, keyakinan, dan doktrin yang berkembang di masyarakat Barat? Berdasarkan kenyataan tersebut, maka sudah sewajarnya perlu dihadirkan Antropologi alternatif yang dikembangkan di Indonesia dengan berdasarkan sudut pandang pendekatan yang dipengaruhi oleh sosio-historis-kultural keindonesiaan. Kristalisasi cara pandang yang diwarnai sosio-historis-kultral inilah yang disebut Pancasila, maka sudah logis bila bangsa Indonesia mengembangkan Antropologi Pancasila.

Persoalan kedua, terkait landasan ontologis ilmu adalah apa objek kajian Antropologi Pancasila. Sesuai namanya, maka objek kajian Antropologi adalah manusia Indonesia dengan fenomena fisik dan budayanya. Mungkin muncul pertanyaan, dengan demikian Antropologi Pancasila tidak relevan untuk membahas manusia selain manusia Indonesia? Antropologi Pancasila tidak menutup kemungkinan membahas manusia lain, selain manusia Indonesia, namun semua itu harus dikaitkan dengan manusia Indonesia, artinya manusia Indonesia juga dipahami hidup di antara manusia-manusia lain yang tentu ada saling interaksi dan pengaruh.

Persoalan terakhir, terkait dengan landasan ontologis Antropologi Pancasila adalah apa asumsi para ilmuwan tentang objek kajian tersebut. Para pemikir Antropologi Pancasila kiranya bersepakat bahwa manusia Indonesia itu selain memiliki sifat keumuman dan personal, namun ada satu pengikat yang merupakan karakteristik kolektifnya. Karakteristik itu dikenal dengan semboyan, "Bhinneka Tunggal Ika”, artinya manusia Indonesia memiliki keragaman suku, agama, ras, dan golongan yang beraneka ragam, namun semuanya dapat dipersatukan dalam satu wadah keindonesiaan. Keragaman dalam bingkai persatuan inilah yang menjadi dasar keyakinan ontologis ilmuwan Antropologi Pancasila dalam memaknai objek kajian Antropologi.

Ketiga dasar ontologis di atas, kiranya tidak dapat dilepaskan dari landasan filosofis yang lain, yaitu landasan epistemologis dan aksiologis Antropologi Pancasila. Keyakinan ontologis antropolog yang mengembangkan Antropologi Pancasila ini akan mempengaruhi pandangannya epistemologisnya, terutama tentang sumber, jenis, metode dan validitas pengetahuan, maupun pandangan aksiologisnya terutama tentang hubungan antara ilmu dan nilai, tujuan pengembangan ilmu dan sikap ilmiah yang harus dikembangkan. Intinya semua itu harus didasarkan pada nilai-nilai Pancasila.

Antropologi Pancasila sangat memungkinkan dikembangkan dalam cabang Antropolgi yang berkembang dewasa ini seperti Antropologi ekonomi, Antropologi kependudukan, Antropologi politik, Antropologi hukum, Antropologi linguistik, Antropologi kognitif, Antropologi perkotaan, Antropologi kesehatan, Antropologi ekologi, Antropologi pendidikan, antropologi kuliner, antropologi wisata, dan sebagainya. Ciri pembedanya adalah dasar nilai yang dijadikan dasar untuk menilai kebenarankesalahan, kebaikan-keburukan, dll.

Untuk menunjukkan karakteristik yang menonjol dari dasar ontologis Antropologi Pancasila, berikut ini akan diuraikan keyakinan prinsipial yang diturunkan dari Pancasila yang dapat dijadikan landasan dalam pengembangan Antropologi.

Pancasila memuat prinsip-prinsip dasar yang lahir dari nilai-nilai agama/kepercayaan, budaya, dan tata kemasyarakatan bangsa Indonesia. Dari ketiga nilai dasar terebut kemudian terwujud dalam sila-sila Pancasila. Seperti dijelaskan oleh Surono (dalam Mustansyir, dkk: 2018) sebagai berikut. Pertama, ketuhanan. Bahwa, seluruh bangsa Indonesia mengakui adanya Tuhan sebagai kekuatan di atas manusia. Prinsip ketuhanan pada masyarakat ini sangat nyata terlihat pada berbagai upacara/ritual masyarakat. Misalnya, upacara/ritual yang berhubungan dengan siklus hidup dari lahir sampai mati, bahkan pascakematian. Pada level yang lebih nyata lagi, adanya asas keberagaman dalam beragama untuk saling menghormati dan bersikap toleran.

Kedua, kemanusiaan. Dalam hal ini masyarakat dan budaya bangsa sangat menjunjung tinggi nilai 
kemanusiaan yang adil dan beradab. Nilai-nilai yang berkembang dalam masyarakat Indonesia zaman dahulu adalah saling menghargai, saling menolong, tidak menyepelekan orang lain, dan sebagainya. Bukan semangat saling menindas, saling menjajah, maupun saling memperalat. Nilai-nilai kemanusiaan seperti itulah yang harus dikaji oleh para antropolog.

Ketiga, persatuan. Nilai-nilai utama yang tidak boleh diabaikan dalam kajian Antropologi adalah nilai-nilai gotong royong, kebersamaan, kolaborasi, saling membantu yang berkembang dalam masyarakat Indonesia. Nilai-nilai persatuan inilah yang harus diangkat dari budaya bangsa. Nilai-nilai persatuan perlu dikaji karena seluruh bangsa Indonesia memiliki nilai-nilai persatuan dalam segala aktifitasnya. Bangsa Indonesia lebih dikenal sebagai bangsa yang menjunjung tinggi semangat komunal, bukan nafsu individualnya.

Keempat, kerakyatan. Nilai kerakyatan pada prinsipnya bahwa rakyat adalah pusat segalanya. Jika dicermati dalam konteks kebangsaan Indonesia, seluruh bangsa Indonesia menganut sistem kerakyatan yang luar biasa. Nilai-nilai kerakyatan yang ada pada bangsa Indonesia salah satunya adalah musyawarah dalam mencapai kesepakatan, nilai kebijaksanaan dalam kepemimpinan, dan sebagainya.

Kelima, nilai-nilai keadilan. Bangsa Indonesia dikenal sebagai bangsa yang adil. Salah satu contohnya adalah konsep mukti bareng yang dimiliki orang Jawa. Konsep tersebut memiliki makna bahwa kesejahteraan yang sesungguhnya adalah ketika semua orang sudah sejahtera. Ketika kesejahteraan hanya dimiliki oleh individu, maka sejatinya kesejahteraan belum tercapai.

Berdasarkan penjelasan di atas maka Pancasila tersusun dari nilai-nilai sprititual dan nilai-nilai komunal atau persaudaraan. Spiritualitas merupakan nilai utama yang akan dituju sementara nilai-nilai persaudaraan menjadi fondasi menuju ke-llahian. Nilai-nilai persaudaraan ini sangat pantas menjadi modal bangsa Indonesia. Karena Indonesia adalah bangsa dan negara yang bhinneka, terdiri dari berbagai suku bangsa, bahasa, agama, dan lain sebagainya. Ketika diikat dalam satu ikatan bernama Indonesia, maka dibutuhkan semangat kebersamaan dari bebagai perbedaan yang ada. Semangat persaudaraan tersebut akan sampai pada puncaknya ketika dilandasi dengan semangat pengabdian diri kepada Tuhan.

\section{Simpulan dan Saran}

Berdasarkan kajian di atas, kiranya dapat disimpulkan sebagai berikut. Pertama, Antropologi Pancasila adalah Antropologi alternatif yang dikembangkan di Indonesia dengan menjadi Pancasila sebagai landasan filosofis pengembangan keilmuan Antropologi, yang memiliki karakteristik tersendiri dibandingkan dengan Antropologi mainstream yang memiliki landasan ontologis, epistemologis, dan aksiologis yang khas. Kedua, eksistensi Antropologi Pancasila dapat dijelaskan dengan argumentasi objek kajian dan sudut pandang pendekatan yang digunakan. Objek kajian Antropologi Pancasila adalah manusia Indonesia dengan karakteristiknya yang berbhinneka tunggal ika, yang tidak dapat sepenuhnya dipahami dengan pendekatan non-Indonesia. Antropologi Pancasila mengkaji manusia Indonesia dengan perspektif Pancasila. Ketiga, keyakinan ontologis para ilmuwan pengembang Antropologi Pancasila ini akan mewarnai pandangan mereka tentang landasan epistemologis (terutama terkait dengan sumber kebenaran, jenis pengetahuan, serta validitas kebenaran) dan landasan aksiologis (terutama terkait dengan hubungan antara ilmu dan nilai, tujuan pengembangan ilmu, dan sikap ilmiah).

\section{Daftar Pustaka}

Ahimsa-Putra, Heddy Shri. 2008. "Paradigma dan Revolusi IImu dalam Antropologi Budaya". Pidato Pengukuhan Jabatan Guru Besar pada Fakultasi Ilmu Budaya. Universitas Gadjah Mada.

Bakker, A., \& Zubair, A. C. 1990. Metode Penelitian Filsafat. Yogyakarta: Penerbit Kanisius.

Bakker, Anton. 2000. Antropologi Metafisik. Yogyakarta: Penerbit Kanisius.

Bakry, Noor MS., 1994. Orientasi Filsafat Pancasila. Yogyakarta: Penerbit Liberty.

Budisutrisno, 2006. "Teiru Kebenaran Pancasila Sebagai Dasar Pengembangan Ilmu”. Jurnal Filsafat Vol 19, April 2006: 57-76.

Haviland, William A. 1999. Antopologi, Jilid 1, Alih Bahasa: R.G. Soekadijo. Jakarta: Erlangga.

Kaplan, David \& Albert A. Manners. 1999. Teori Budaya. Yogyakarta: Pustaka Pelajar.

Koentjaraningrat. 1981. Pengantar Ilmu Antropologi. Bandung: Rineka Cipta.

Mubyarto. 1997. Ekonomi Pancasila Lintasan Pemikiran Mubyarto. Yogyakarta: Aditya Media.

Mudhofir, Ali. 1996. "Pancasila Sebagai Sistem Kefilsafatan”. Jurnal Filsafat, edisi Desember 1996.

Mustansyir, Rizal., Heri Santoso, \& Surono. 2018. Bunga Rampai Rekonstruksi IImu Kepancasilaan dalam Ranah Akademis. Yogyakarta: Pusat Studi Pancasila UGM. 
Notonagoro, 1951. Pantjasila Dasar Filsafat Negara Republik Indonesia. Yogyakarta: Unversitas Gadjah Mada.

Notonagoro, 1975. Pancasila Secara IImiah Populer. Jakarta: Pantjuran Tujuh.

Oesman, Oetojo \& Alfian (penyunting). 1991. Pancasila Sebagai Ideologi dalam Berbagai Bidang Kehidupan Bermasyarakat, Berbangsa, dan Bernegara. Jakarta: BP-7.

Pels, Peter. 2018. "Anthropology Should Never Be Fully Decolonized". Etnofoor, Vol. 30(2), 71-76.

Pranarka, A.M.W. 1985. Sejarah Pemikiran tentang Pancasila. Jakarta: CSIS.

Prawirohardjo, Soeroso H., Anton Bakker, \& Slamet Soetrisno (ed.). 1986. Pancasila Sebagai Orientasi Pengembangan IImu. Yogyakarta: Badan Penerbit Kedaulatan Rakyat.

Santoso, Heri. 1999. "Konsep Pribumisasi Ilmu Sosial di Indonesia Abad XX". Thesis. Yogyakarta: Program Pascasarjana Fakulstas Filsafat Universitas Gadjah Mada.

Santoso, Heri., Rizal Mustansyir, Sindung Tjahyadi, \& Surono., 2016. Bunga Rampai: Pengembangan IImu Kepancasilaan di Indonesia. Yogyakarta: Pusat Studi Pancasila UGM.

Taylor, A. E. 2015. Aristotle. New York: Dodge Publishing co. 